\title{
Study on the Determination and Control of the Construction Cost Liqun Wang ${ }^{1, a}$ \\ ${ }^{1}$ Pingxiang University, Pingxiang, Jiangxi, 337055 \\ a email
}

\author{
Keywords: Determination and Control, Construction Cost, Project Efficiency
}

\begin{abstract}
With China continues to participate in international competition, domestic market continues to open up our country in the world economic system, and we have shown a pivotal position. In these objective conditions, reform of the economic management of the relevant system, reform of the current management system and management models, with truly international management standards is essential. With the continuous deepening and further improvement in the construction field, the implementation of the project legal system, the bidding system, the construction supervision system and contract management system, independent quoted market price formation of Project Cost of the socialist market economic system management system is taking shape.
\end{abstract}

\section{Introduction}

In recent years, capital investment has become the driving force to promote China's economic growth, with the construction of saving society, saving capital investment is to save the wealth of society, has become an issue in front of each project manager. Ability to accurately identify and effectively control project cost, in order to achieve the project objectives, to improve the return on investment, saving social resources, become the common goal of all parties participating in the construction project. At present the results of theoretical and methodological research project cost of applications to professional management background and the actual implementation of specific projects were analyzed, focusing on the design and construction phases of cost management in the actual work of making application to explore, trying corresponding mathematical tools and expertise to establish the relevant mode, and then for the application in practical work play a guiding significance. Looking to accurately determine and control the project cost effective ways and means, for the subject of this writing raised.

\section{Construction Project Cost Management}

Cost is the main object of study construction project cost management. Understanding and theoretical study of the project cost concept is the basis of the work of Project Cost Management. The cost of the project cost of both cost (cost) meaning, but also the purchase price (Price) meaning. China Construction Cost Management Association were given two meanings of the project cost. The first refers to the sum of the completion of a construction project investment costs, the second refers to the price of building products.

Project cost management is based on the construction project for the study, with engineering and technology, economics, management as a means to benefit as the goal, technology, economics, management, combining a cross, the emerging interdisciplinary. Project cost has two meanings, with the corresponding project cost management also has two meanings: the construction project cost management of investment and construction projects price management.

Project investment cost management belongs to the category of investment management, in order to achieve certain targets in the planning, design of the proposed conditions, forecast, calculations to determine and monitor system activity and changes in project cost. This means covering the micro-level management of the project investment costs, but also covers the macro-level investment management fees.

It includes determining reasonable and effective control of the project cost of a series of work. 
Reasonably determine the project cost, ie at all stages of the construction process, the use of scientific and practical basis for valuation to determine a reasonable estimate of the investment, design estimates, construction budget, contract price, completion and final settlement price settlement price. Effective control of the project cost, namely in the investment decision-making phase, design phase, construction project contracting and implementation phases, the construction project cost control within the approved cost limit at any time to correct the error occurred, in order to ensure that the project investment control goals.

Price management project management belong price category. Price management can be divided into micro-level and macro levels in two ways. Micro level refers to the cost control companies in control of the market price on the basis of information to achieve management objectives carried out, valuation, pricing and bidding system activity, reflected by the main micro economic laws govern price movement. Macro-level government according to the needs of economic development, the use of legal means, economic means and administrative means to manage price and regulation as well as through market management, market players to regulate system activity price behavior.

\section{Objectives and Features of Project Cost Management}

Fundamentally speaking, the project cost-effective investment management services to construction projects, one of the objectives of the project cost management cost is therefore itself (input-output ratio) is reasonable; second is to make the project investment is always in control. Because only guarantee these two goals, the construction project can proceed smoothly and achieve the core objectives of the construction project as planned. In particular the management process should follow the rules of market economy, improve the price control mechanism to achieve the optimal allocation of resources, foster and standardize the construction market in labor, technology, information and other market factors, the use of scientific management methods and advanced management tools, reasonably determine the project cost, use reasonable investment, effectively control project cost, in order to improve investment efficiency construction projects.

Project cost management features mainly in the following areas: timeliness, reflecting the characteristics of the price within a certain period, that changes with time and constantly changing. Impartiality, it is necessary to maintain the owners (investors) the legitimate rights and interests, but also to safeguard the interests of the contractor, standing on the fair position Satisfy. Normative, since projects vary widely, basic elements of cost and easy to be decomposed to facilitate the measurement of assumed comparable products, which requires objective standards, procedures specification. Accuracy, that the use of scientific, technical and legal principle means management, metering, pricing, billing reasonable, according to the law.

\section{Basic Contents of Project Cost Management}

Content Project cost management and effective control is to reasonably determine the project cost, the main contents include:

Project decision-making stage is that, according to the function of the proposed project requirements and requirements to make the project definition, including the definition of investment. And in accordance with the requirements of the project planning of investment estimation, the investment estimated error rate was controlled within the permissible range.

Preliminary design stage, the use of design standards and standard design, value engineering approach, limit design method, the feasibility study report approved project cost estimated investment target, control the preliminary design. If investment estimation design estimates exceed the allowable error, deal with the preliminary design adjustments and modifications. Reasonably determine the so-called project cost, which is in various stages of the construction process, determine a reasonable estimate of the investment, cost estimates, budgetary cost, the contract price, the settlement price, completion and settlement price.

Construction design stage and should be based on the approved design estimates for the control target, limit application design, value engineering and other methods, \# design estimates to control 
construction plans actually work. If the construction drawing budget estimates beyond the design, then the construction design of the contents of breakthrough design principles preliminary project design requirements, and thus to deal with construction design modifications and adjustments. Through the project cost design process of the formed layers quota design, implementation, project design stage construction cost control objectives.

Construction preparation phase to engineering design (including an estimated budget) based on the specific circumstances of the construction, such as site conditions, market prices, the owners of the special requirements, preparation of tender documents, to determine the base price, select contract pricing, determine construction contracts price.

\section{Implement Effective Control of Construction Cost}

Construction project investment decision-making is the process of program choices and decisions, and this process should be timely to compare different options to make the right judgments and decisions. Construction project cost control throughout the entire process of project construction, investment and design phase of the project before the implementation of the project is the key to cost control. According to some foreign countries to analyze the impact of the construction cost of the project design cost is very large, occupies a very important position. But at this stage of pre-project engineering neglect cost control, focus on the implementation phase of the project, such as construction drawing budget audit, a reasonable settlement, this approach has some effect, but time-consuming, they do not see very clear effect. To Construction Cost effective control, it must take the planning and design stages of the Project cost control as the top priority. In the planning and design process, the focus is to consider the cost and the size of two factors. This is very important for the construction side, will directly affect the investment control of construction projects.

Investor willingness to shift from the idea stage to reality is the design phase. Design phase of the project can be implemented cost control and design bidding system, the development of rational design, to reduce the possibility of the construction phase of major changes in the program, effectively control project cost. If you participate in the engineering design engineering supervision, we can exclude a lot of negative factors. During the project construction, during the construction phase, the cost savings can only control a small part of the cost of construction of the control can save a lot. During the design phase, supervision according to design drawings and descriptions, with the owners of the different design options, cost analysis. The design phase is about to start building the project has no specific implementation stage, the construction project cost control, during the construction phase in order to avoid large changes, because the design to reduce construction cost increases caused by, so to detailed design.

In the implementation of construction projects, the construction unit to strictly tender documents and engineering contract signed. Tender stage to control the project cost, it is necessary to accurately grasp the design drawings, detailed analysis of the situation of the construction project, the audit qualification of bidders, thus the preparation of tender documents, and then select the successful bidder, the contract price is determined.

Construction stage design drawings into actual construction process, to strengthen the management of the construction process. At this stage, should be placed on contract management. Cost management personnel to proactively monitor the entire project, the need for change works strictly from all angles to consider whether you need to change in order to reduce unnecessary expenses. Construction technology for effective control of project investment, new technology and new materials to shorten the duration, improve labor productivity. Project implementation phase of the project cost, can be combined with the progress of works, metering project, to accurately grasp the engineering design, design changes to be strictly and promptly correct the wrong place, strengthen contract management, engineering claims control, strengthen the construction supervision. 


\section{Conclusion}

Construction project cost control is a dynamic process, throughout the whole process of project construction. We want to effectively control the construction project cost, optimize the use of funds, reduce investment costs and ensure a reasonable scientific project cost. In addition to the project cost control, to reduce investment costs is more importantly, is to urge the construction unit and construction unit design units in close cooperation, so human, financial and material resources should be fully utilized to bring the best social benefits, thus speeding up the social and economic development.

\section{References}

[1] Seeley I. H. Building economics. Macmillan London. UK. 1996

[2] Boussabaine A. H. The use of artificial neural networks in construction management. Construction Manager. 1996

[3] Azad K K. On semi-continuity fuzzy almost continuity and fuzzy weakly continuty. Journal of Mathematical Analysis and Applications. 1981

[4] D. K. H. Chua, D. Li. Key Factors in Bid Reasoning Model. Journal of Construction Research. 2000

[5] Akintoye A. Analysis of factors influencing project cost estimating practice. Construction Manager. 2000

[6] Caudill M, Butler C. Naturally intelligent systems. 1990 